\title{
Evaluation of respiratory syncytial virus IgG antibody dynamics in mother-infant pairs cohort
}

\author{
Mehmet Yildiz ${ }^{1}$ (D) Manolya Kara ${ }^{2} \cdot$ Murat Sutcu $^{2} \cdot$ Sevim Mese $^{3} \cdot$ Mehmet Emin Demircili $^{3} \cdot$ Tugba Sarac Sivrikoz $^{4}$. \\ Selda Hancerli Torun ${ }^{2} \cdot$ Ali Agacfidan ${ }^{3} \cdot$ Asuman Coban $^{5} \cdot$ Emin Unuvar $^{6} \cdot$ Ayper Somer $^{2}$
}

Received: 25 December 2019 / Accepted: 5 February 2020 / Published online: 14 February 2020

(C) Springer-Verlag GmbH Germany, part of Springer Nature 2020

\begin{abstract}
RSV is one of the most important agents of lower respiratory infections in childhood. In this study, anti-RSV antibody levels in mother-infant pairs and factors related to antibody transfer ratio were investigated. One hundred and twenty-seven women that had term babies and their babies and 84 mother-infant pairs of them who continued the study after 6 months were enrolled. AntiRSV IgG antibodies of the mothers and infants were positive in $46.5 \%$ and $61.5 \%$, respectively. At the sixth month, anti-RSV antibodies were negative in all infants. Median of the anti-RSV antibody levels of the mothers and infants at birth were $12.08 \mathrm{IU} /$ $\mathrm{ml}(1.21-119.27)$ and $13.78 \mathrm{IU} / \mathrm{ml}$ (3.99-108.6), respectively. There was a significant correlation between anti-RSV antibody levels of mothers and infants at birth ( $p: 0.0001, \mathrm{r}: 0.667)$ and anti-RSV antibody levels of infants at birth and at 6th month ( $p$ : 0.0001, r: 0.343). Median ratio of infant and mother antibody levels was $1.22(0.14-6.05)$. Median ratio that was detected in appropriate for gestational age infants was significantly higher than in small for gestational age or large for gestational age infants. In this study, the significant positive correlation between maternal antibody levels and infants' antibody levels at birth suggests that maternal vaccination strategies may be logical. We showed that antibody transfer rate was highest in appropriate for gestational age infants. It should be kept in mind that maternal vaccination strategies may be less effective in small for gestational age and large for gestational age infants.
\end{abstract}

Keywords Respiratory syncytial virus $\cdot$ Maternal antibodies $\cdot$ Passive immunization $\cdot$ Transplacental antibody transfer

Mehmet Yildiz

yildizmehmet@istanbul.edu.tr

\begin{abstract}
Abbreviations
RSV Respiratory syncytial virus

LRTI Lower respiratory tract infection

SGA Small for gestational age

AGA Appropriate for gestational age

LGA Large for gestational age
\end{abstract}

\section{Introduction}

Lower respiratory tract infections (LRTI) are one of the major causes of morbidity and mortality in children in the preschool age group all over the world, especially in developing countries [1]. In a meta-analysis conducted in 2013, the incidence of pneumonia in children under 5 years was 0.22 episodes per child per year [2]. One hundred and fifty million new cases of pneumonia occur all over the world per year; $7-13 \%$ of these cases require hospitalization and LRTIs caused $19 \%$ of children deaths under 5 years [3]. In the light of these data, LRTIs are 
particularly have been striking as a significant public problem due to its high mortality and morbidity rates in children under 5 years of age.

In children, LRTIs can be caused by various microorganisms. The most frequent viral causes of LRTIs, especially in children under 2 years, are respiratory syncytial virus (RSV), influenza virus, parainfluenza virus, and adenovirus [4]. RSV is the most common viral agent in childhood LRTIs [5]. There is no proven treatment option other than adequate hydration and oxygenation for RSV infections [6]. Therefore, protection from RSV infections is crucial. In recent years, efforts to develop vaccines against RSV infections have gained momentum. Vaccine development efforts focus on early childhood vaccination or protection of babies by antibodies that are transplacentally transported to babies from immunized mothers. While vaccine development studies are ongoing, it is important to understand RSV immunity to determine RSV Ig $\mathrm{G}$ antibody seropositivity rates in mother-infant pairs and to evaluate the transplacental antibody transfer kinetics.

For this purpose, we investigated RSV antibody levels at birth and 6th month (only infant's antibody levels) of age and evaluated the factors related to antibody transfer ratio in 84 mother-infant pairs.

\section{Material and methods}

\section{Study population, definitions}

The patients who were admitted to Istanbul Faculty of Medicine, Department of Obstetrics and Gynecology for delivery between January 2016 and April 2016 were informed in detail for the study.

Written consent was obtained from the families who were interviewed and agreed to participate in the study. Family contact information, gestation week, type of delivery, gravidity, parity, number of school-aged siblings, household members, and smokers at home were asked to parents.

Infants that were born between $37+0 / 7$ and $38+6 / 7$ weeks of gestation were defined as early term, those that were born between $39+0 / 7$ and $40+6 / 7$ weeks of gestation were defined as full term, and that those were born between $41+0 / 7$ and $416 / 7$ weeks of gestation were defined as late term [7].

Infants were divided into 3 groups according to their birth weights: small for gestational age (SGA), appropriate for gestational age (AGA), and large for gestational age (LGA). According to the fetal birth weight percentiles, infants were defined as SGA if their birth weight were less than 10th percentile, AGA if their birth weight were between 10 and 90 percentile, and LGA if their birth weight were above 90th percentile [8].

\section{Sampling}

Before delivery, when vascular access was opening, 2-mL blood sample was taken from the mothers. Babies' blood samples $(2 \mathrm{ml})$ were taken via umbilical cord immediately after birth. Blood samples were stored at $-70{ }^{\circ} \mathrm{C}$ until

Table 1 Sociodemographic characteristics of the cases

\begin{tabular}{|c|c|}
\hline Characteristics of mothers & $n(\%)$ or mean $\pm \mathrm{SD}$ \\
\hline Mean age & $30.4 \pm 5.4$ \\
\hline \multicolumn{2}{|l|}{ Gravidity } \\
\hline$\leq 2$ & $75(59.1)$ \\
\hline $2-4$ & $26(20.5)$ \\
\hline$\geq 4$ & $26(20.5)$ \\
\hline \multicolumn{2}{|l|}{ Parity } \\
\hline$\leq 2$ & $113(89)$ \\
\hline $2-4$ & $9(7.1)$ \\
\hline$\geq 4$ & $5(3.9)$ \\
\hline \multicolumn{2}{|l|}{ Delivery type } \\
\hline Vaginal & $26(20.5)$ \\
\hline Cesarean section & $101(79.5)$ \\
\hline \multicolumn{2}{|l|}{ Number of household members } \\
\hline$\leq 2$ & $25(19.7)$ \\
\hline $2-4$ & $29(22.8)$ \\
\hline$\geq 4$ & $73(57.5)$ \\
\hline Smoking by household members & $66(52)$ \\
\hline Characteristics of infants & $n(\%)$ or mean $\pm \mathrm{SD}$ \\
\hline \multicolumn{2}{|l|}{ Gender } \\
\hline Male & $62(48.8)$ \\
\hline Female & $65(51.2)$ \\
\hline \multicolumn{2}{|l|}{ Weeks of Gestation } \\
\hline Early term & $72(56.7)$ \\
\hline Full term & $47(37.0)$ \\
\hline Late term & $8(6.3)$ \\
\hline \multicolumn{2}{|l|}{ Birth weight } \\
\hline Small for gestational age & $8(6.3)$ \\
\hline Appropriate for gestational age & $93(73.2)$ \\
\hline Large for gestational age & $26(20.5)$ \\
\hline Exclusive breastfeeding & $46(54.7)$ \\
\hline Bronchiolitis history & $24(28.5)$ \\
\hline \multicolumn{2}{|l|}{ Number of siblings } \\
\hline$\leq 2$ & $107(84.3)$ \\
\hline $2-4$ & $13(10.2)$ \\
\hline$\geq 4$ & $7(5.5)$ \\
\hline \multicolumn{2}{|l|}{ Number of school-aged siblings } \\
\hline$\leq 2$ & $118(92.9)$ \\
\hline $2-4$ & $7(5.5)$ \\
\hline$\geq 4$ & $2(1.6)$ \\
\hline
\end{tabular}


processing after they were rapidly centrifuged at 3000 $3500 \mathrm{rpm}$ for $15 \mathrm{~min}$.

Six months after birth, the parents whom could be reached were reinterviewed. And control blood samples were taken after informed consents were obtained. Blood samples were stored at $-70{ }^{\circ} \mathrm{C}$ until processing after they were rapidly centrifuged at 3000-3500 rpm for $15 \mathrm{~min}$, and $2 \mathrm{~mL}$ of blood samples were taken from infants.

\section{Detection of RSV antibody levels in serum samples}

In our study, anti-RSV Ig G antibody levels in serum samples were determined by ELISA method in the Department of Virology and Basic Immunology of Istanbul University Istanbul Medical Faculty. The ELISA test was performed automatically on a Triturus (Grifols, Spain, Serial No. 053-195-1484) instrument using the Serion ELISA classic (Viron/Serion, Germany, Catalog No. 13.13 / 09-1) kit.

Serum samples were thawed at $-70{ }^{\circ} \mathrm{C}$ to $+4{ }^{\circ} \mathrm{C}$ the day before the testing began. Patient specimens and control sera were identified in the Triturus analyzer. At the end of the study, the optical densimeter values obtained for the blank, control sera, and patient samples were manually entered into the "Serion activity 11" program. The values of the quality control certificate were used for the standard curve of the program. Patient results from the Serion activity 11 program were quantified as "IU/mL." This program interprets the quantitative measurements as negative, intermediate, and positive according to the cutoff values given in the certificate.

\section{Statistical analysis}

Statistical analysis was performed with SPSS version 21.0 (IBM, Armonk, NY).The Kolmogorov-Smirnov test was used for analyzing the distributions of variables. Categorical variables were reported as numbers and percentages. Continuous variables with normal distribution were given as mean \pm standard deviation (SD) while those with non-normal distribution were presented as median (minimum-maximum). Categorical data were compared by the $\chi 2$ test and Fisher's exact test. Normally distributed continuous variables were compared by Student's T test. Mann-Whitney U test or Kruskal Wallis test were used for continuous variables, which are not normally distributed according to number of groups. Relations between quantitative variables were evaluated by

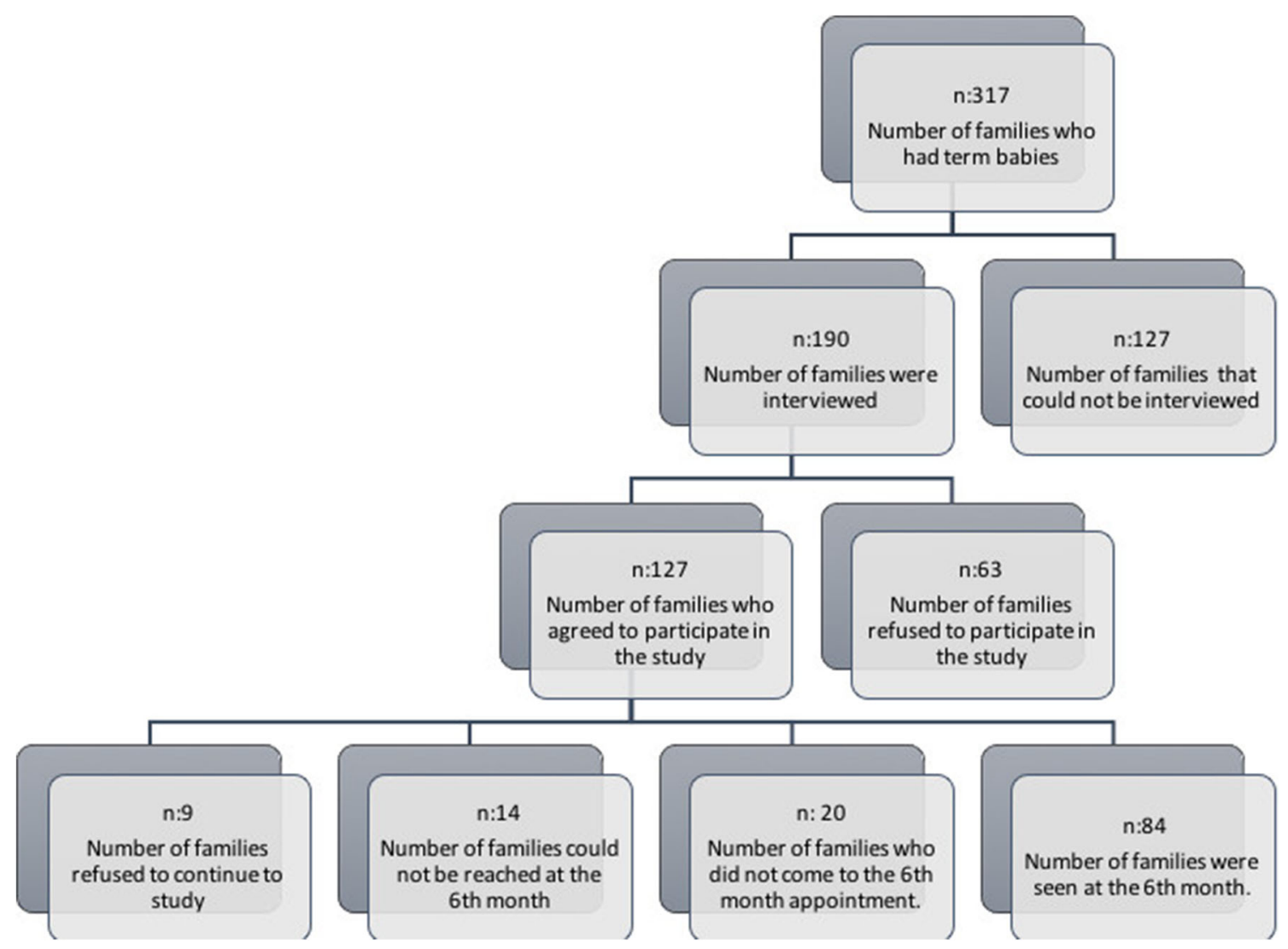

Fig. 1 Flowchart diagram. Schematic representation of patient group 
Table 2 Anti-RSV antibody positivity rates and levels of mothers and infants

\begin{tabular}{lc}
\hline & $n(\%)$ \\
\hline $\begin{array}{l}\text { Positivity rates of anti-RSV antibody levels of mothers } \\
\text { Positive }\end{array}$ & $59(\% 46.5)$ \\
Borderline & $10(\% 7.9)$ \\
Negative & $58(\% 45.7)$ \\
Positivity rates of anti-RSV antibody levels of infants (at birth) \\
Positive & $78(\% 61.5)$ \\
Borderline & $4(\% 3.1)$ \\
Negative & $45(\% 35.4)$ \\
& \\
Positivity rates of anti-RSV antibody levels of infants (6th month) & \\
Positive & 0 \\
Borderline & $84(\% 100)$ \\
Negative & Anti-RSV antibody level \\
& $12.08 \mathrm{IU} / \mathrm{ml}(1.21-119.27)$ \\
Anti-RSV antibody levels of mothers & \\
(median, range) & \\
Anti-RSV antibody levels of infants & $3.42 \pm 0.43$ IU/ml \\
At birth (median, range) & \\
6th month (mean $\pm S D)$ & \\
\hline
\end{tabular}

Spearman's correlation coefficient. In all analyses, a value of $p<0.05$ was considered as statistically significant.

\section{Ethics statement}

Our study was found to be ethically acceptable by Istanbul University Istanbul Faculty of Medicine Clinical Research Ethics Committee (2015/1816). Written informed consent was obtained from all of the participants' parents.

\section{Results}

Sociodemographic characteristics of the cases and schematic representation of patient group are shown in Table 1 and Figure 1. Anti-RSV IgG antibodies of the mothers were positive in $46.5 \%$, negative in $45.7 \%$, and borderline in $7.9 \%$. Anti-RSV IgG antibodies of infants at birth were positive in $61.5 \%$, negative in $35.4 \%$, and borderline in $3.1 \%$. At the sixth month, anti-RSV antibodies were negative in all infants. Median of the anti-RSV antibody levels of the mothers and infants at birth were $12.08 \mathrm{IU} / \mathrm{ml}(1.21-119.27)$ and $13.78 \mathrm{IU} /$ $\mathrm{ml}$ (3.99-108.6), respectively. Mean anti-RSV antibody levels of infants at 6th month were $3.42 \pm 0.43 \mathrm{IU} / \mathrm{ml}$ (Table 2). AntiRSV IgG antibody levels of the mothers and infants (at birth and 6th month) are shown in Figure 2.

Median ratio of cord antibody level to maternal antibody level was $1.22(0.14-6.05)$.In order to investigate the affecting factors to the transfer of antibodies from mother to baby, "the ratio of cord antibody level to maternal antibody level" was compared
Fig. 2 Anti-RSV IgG antibody levels of the mothers at birth and infants at birth and 6th month

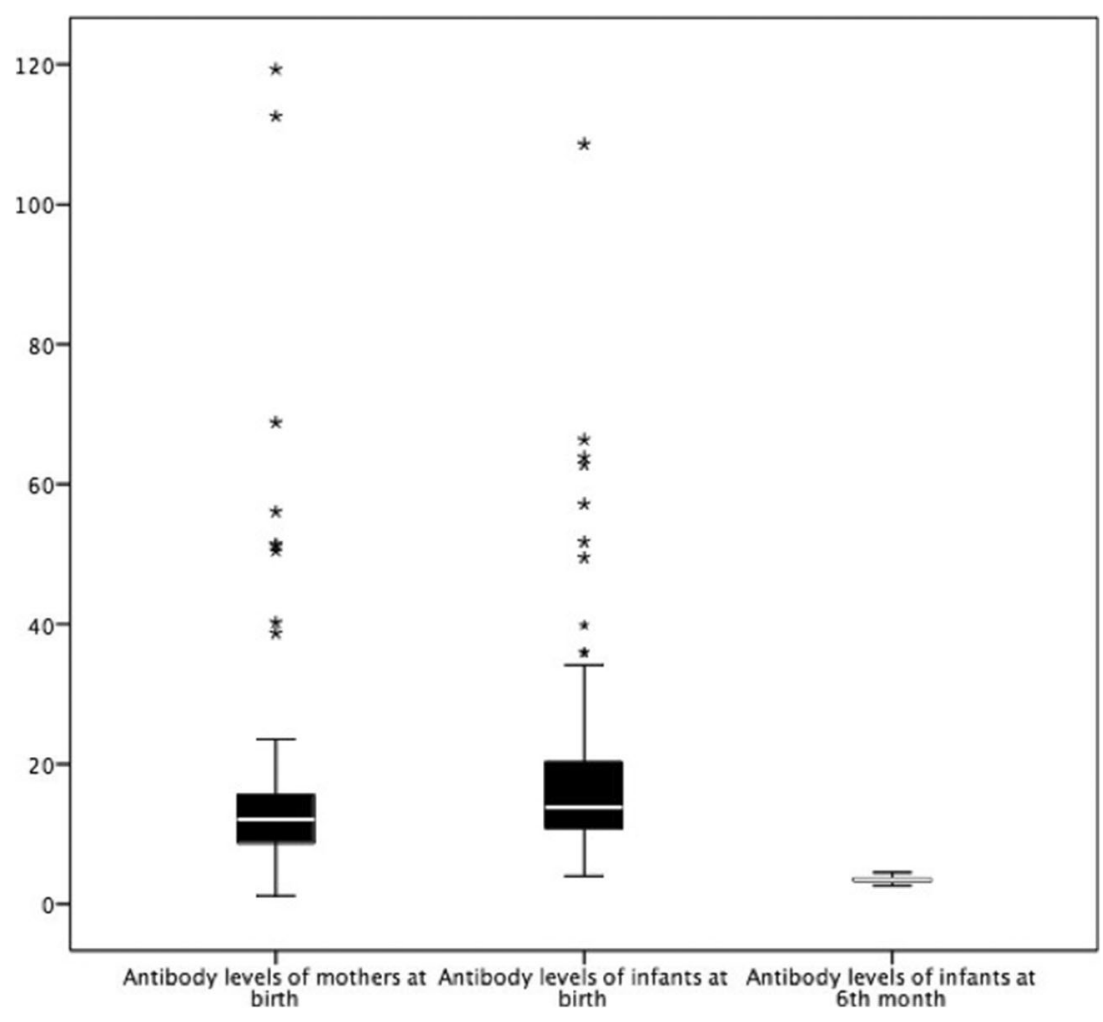


according to gender, type of delivery, gestation week, birth weight, and the number of gravidity and parity. Median ratio that was detected in AGA infants was statistically higher than the median ratio detected in SGA or LGA infants (Table 3).

Anti-RSV antibody levels of infants at birth and 6th month were compared according to factors may affect the antibody levels. There were no significant differences at birth and at 6th month between groups for each factor (Tables 4 and 5).

There was a statistically significant and strong correlation between anti-RSV antibody levels of mothers and infants at birth ( $p: 0.0001, \mathrm{r}: 0.667)$ and anti-RSV antibody levels of infants at birth and at 6 months of age ( $p: 0.0001, \mathrm{r}: 0.343)$ (Fig. $3 \mathrm{a}$ and $\mathrm{b}$ ).

\section{Discussion}

In this prospective study, we reported an effective anti-RSV antibody transfer from mother to infant. In addition, we have showed that the antibody transmission rate is optimal in AGA infants. To our best knowledge, it is the first study reporting

Table 3 Comparison of ratio of cord antibody level to maternal antibody level according to gender, type of delivery, gestation week, birth weight, and the number of gravidity and parity

Ratio of cord antibody level p to maternal antibody

level median (min-max)

\begin{tabular}{lll}
\hline Gender & & \\
$\quad$ Male & $1.14(0.36-6.05)$ & $0.17^{*}$ \\
$\quad$ Female & $1.33(0.14-2.6)$ & \\
Delivery type & & \\
$\quad$ Vaginal & $1.34(0.22-2.28)$ & $0.44^{*}$ \\
$\quad$ Cesarean section & $1.21(0.14-6.05)$ & \\
Gestation week & & $0.19 \dagger$ \\
Early term & $1.26(0.63-6.05)$ & \\
Full term & $1.14(0.14-4.5)$ & \\
Late term & $1.32(0.96-2.35)$ & \\
Birth weight & & \\
$\quad$ Small for gestational age & $1.25(0,87-2.34)$ & \\
Appropriate for gestational age & $1.29(0.14-6.05) \ddagger$ \\
Large for gestational age & $1.10(0.36-1.72)$ & \\
Number of gravidity & & \\
$\leq 2$ & $1.22(0.22-6.05)$ & \\
$2-4$ & $1.31(0.63-4.5)$ & \\
$\geq 4$ & $1.15(0.14-2.34)$ & \\
Number of parity & & \\
$\leq 2$ & $1.22(0.22-6.05)$ & \\
$2-4$ & $1.22(0.14-1.82)$ & \\
$\geq 4$ & $1.15(0.95-2.25)$ & \\
\hline
\end{tabular}

*Mann-Whitney U

$†$ Kruskal Wallis (Mann-Whitney U)

$¥$ Significantly higher than other groups
Table 4 Comparison of anti- RSV antibody levels of infants at birth according to gender, gravidity, parity, type of delivery, gestation week, and birth weight

Anti-RSV antibody levels

$p$ of infants at birth (IU/ml)

median (min-max)

\begin{tabular}{lcc}
\hline Gender & & \\
Male & $13.86(4.48-108.6)$ & $0.96^{*}$ \\
Female & $13.7(3.99-62.8)$ & \\
Gravidity & & \\
$\leq 2$ & $13.7(4.48-108.6)$ & $0.15 \dagger$ \\
$2-4$ & $16.6(7.2-66.3)$ & \\
$\geq 4$ & $13.1(3.99-27.2)$ & \\
Parity & & \\
$\leq 2$ & $13.7(3.99-108.6)$ & \\
$2-4$ & $16.2(8.03-21.3)$ & \\
$\geq 4$ & $11.5(10-27.2)$ & \\
Delivery type & & \\
Vaginal & $15.1(4.97-108.6)$ & \\
Cesarean section & $13.7(3.99-66.3)$ & \\
Gestation week & & $0.79 \dagger$ \\
Early term & $14.2(3.99-63.8)$ & \\
Full term & $12.5(4.48-66.3)$ & \\
Late term & $14.4(9.89-108.6)$ & \\
Birth weight & & \\
Small for gestational age & $13.6(8.15-57.1)$ & \\
Appropriate for gestational age & $14.2(4.48-108.6)$ & \\
Large for gestational age & $12.9(3.99-24.7)$ & \\
\hline & & \\
& &
\end{tabular}

*Mann-Whitney U

$\dagger$ Kruskal Wallis (Mann-Whitney U)

that anti-RSV antibody transmission rate may be negatively affected in SGA and LGA infants.

In accordance with our results, Chu et al. [9] found the median ratio of cord antibody level to maternal antibody level to be 1.01 and baseline demographic features like age and gender had no effect on it. In another study, it is reported that increasing number of maternal parity and female gender were related with increased antibody transfer [10]. Furthermore, Okoko et al. [11] suggested that low birth weight and prematurity were associated with lower antibody transfer rate for various viruses including RSV.

There are a limited number of studies investigating the effect of weight for gestational age on antibody transfer rate. Yeung et al. [12] reported that IgG levels were lower in "small for dates" infants. It has been reported that transfer rate of all IgG subtypes was negatively affected in premature AGA infants and term SGA infants. In contrast, Addy et al. [13] reported that AGA and SGA infants had similar IgG levels. The conflicting results found in the studies may be related to underlying conditions of the inappropriate birth weights for gestational age. The inappropriate birth weight for gestational age 
can be caused by many conditions associated with the fetus, placenta, or mother, such as hypertension, diabetes, and various placental pathologies. In order to be able to make more accurate statements about this subject, prospective studies are needed by evaluating the conditions causing inappropriate birth weights for gestational age.

The maternal antibody positivity rate in our study was lower than the literature. Up to $98 \%$ seropositivity has been reported in the literature $[14,15]$. Hacimustafaoglu et al. [16] found that $83 \%$ of mothers had anti-RSV IgG antibody positivity in a study conducted in Turkey. The rate reported by Hacimustafaoglu et al. is also lower than the ones in the literature, suggesting that antibody positivity rates may be affected by geographical and climatic characteristics. Supporting to this idea, in a cohort study conducted in Gambia and the USA at the same time, a significant difference in anti-RSV IgG antibody levels was found in infants between the countries [17].

In our study group, $61.5 \%$ of infants had positive anti-RSV IgG antibodies at the time of birth. Forster et al. [18] reported that $99 \%$ anti-RSV IgG positivity was detected in cord blood in a group of infants with an allergic disease history. In another study, Hacimustafaoglu et al. [16] reported that anti-RSV IgG antibody positivity was detected in $83 \%$ of mothers and infants in their study. These high seropositivity rates reported in the literature are inconsistent with our results. The high seropositivity rate reported by Forster et al. [18] was thought to be related to their patient group's atopic characteristics. The low antibody positivity rate reported in our maternal group may have caused to the low antibody positivity rate in infant group at birth.

All blood samples we collected at sixth month had negative anti- RSV Ig G antibody levels. Arankalle et al. [19] found that only $0.7 \%$ of babies who were all positive for RSV antibodies at birth were positive for anti-RSV antibodies at the sixth month. In another study, the infants' anti-RSV IgG antibody positivity rate at sixth month was reported as $16 \%$ [20]. Cox et al. [21] found that maternal antibodies began to diminish at 2nd month and the lowest anti-RSV IgG antibody levels were detected at 6th-8th month. In a similar study, the lowest anti-RSV IgG antibody levels were detected at 5th-6th month [17]. Although there are conflicting reports about the positivity rates at 6th month in the literature, all studies agree that the lowest antibody levels are detected around 5th-7th month.

In accordance with our results, Bhattarakosol et al. [22] reported that they found no relationship between gender and RSV seropositivity. Chu et al. [9] reported that the only variable associated with antibody levels at birth was maternal education. In another study, it is reported that low birth weight and prematurity were associated with low antibody levels of infant [23]. Le Saux et al. [24] found that having at least one child at home was associated with high levels of RSV antibodies at birth.
In our study, there was a statistically significant correlation between cord and maternal antibody level and this correlation suggests that raising maternal antibody levels through maternal inoculation could be a logical strategy for protecting infants from RSV infections.

The most important limitation of our study was that the entire patient group consisted of term babies. As preterm infants are more susceptible to RSV infections, there is a particular need for studies in this population.

Table 5 Comparison of anti-RSV antibody levels of infants at 6th month according to demographic variables

Anti-RSV antibody levels $p$ of infants at sixth months (IU/ml) Mean $\pm \mathrm{SD}$

\begin{tabular}{|c|c|c|}
\hline \multicolumn{3}{|l|}{ Gender } \\
\hline Male & $3.41 \pm 0.45$ & \multirow[t]{2}{*}{$0,97^{*}$} \\
\hline Female & $3.42 \pm 0.40$ & \\
\hline \multicolumn{3}{|l|}{ Delivery type } \\
\hline Vaginal & $3.56 \pm 0.48$ & \multirow[t]{2}{*}{0.09} \\
\hline Cesarean section & $3.37 \pm 0.40$ & \\
\hline \multicolumn{3}{|l|}{ Gestation week } \\
\hline Early term & $3.41 \pm 0.05$ & \multirow[t]{3}{*}{0.89} \\
\hline Full term & $3.41 \pm 0.09$ & \\
\hline Late term & $3.50 \pm 0.13$ & \\
\hline \multicolumn{3}{|l|}{ Birth weight } \\
\hline Small for gestational age & $3.88 \pm 0.53$ & \multirow[t]{3}{*}{0.26} \\
\hline Appropriate for gestational age & $3.42 \pm 0.51$ & \\
\hline Large for gestational age & $3.35 \pm 0.11$ & \\
\hline \multicolumn{3}{|l|}{ Exclusive breastfeeding } \\
\hline Yes & $3.39 \pm 0.47$ & \multirow[t]{2}{*}{$0.57 *$} \\
\hline No & $3.45 \pm 0.37$ & \\
\hline \multicolumn{3}{|l|}{ Bronchiolitis history } \\
\hline Yes & $3.44 \pm 0.30$ & \multirow[t]{2}{*}{$0.61^{*}$} \\
\hline No & $3.40 \pm 0.47$ & \\
\hline \multicolumn{3}{|l|}{ Number of siblings } \\
\hline$\leq 2$ & $3.43 \pm 0.05$ & \multirow[t]{3}{*}{$0.66 \dagger$} \\
\hline $2-4$ & $3.41 \pm 0.11$ & \\
\hline$\geq 4$ & $3.26 \pm 0.13$ & \\
\hline \multicolumn{3}{|l|}{ Number of school-aged siblings } \\
\hline$\leq 2$ & $3.49 \pm 0.46$ & \multirow[t]{3}{*}{0.44} \\
\hline $2-4$ & $3.28 \pm 0.31$ & \\
\hline$\geq 4$ & $3.29 \pm 0.08$ & \\
\hline \multicolumn{3}{|l|}{ Number of household members } \\
\hline$\leq 2$ & $3.36 \pm 0.33$ & \multirow[t]{3}{*}{$0.32 \dagger$} \\
\hline $2-4$ & $3.55 \pm 0.43$ & \\
\hline$\geq 4$ & $3.38 \pm 0.45$ & \\
\hline \multicolumn{3}{|l|}{ Smoking by household members } \\
\hline Present & $3.38 \pm 0.44$ & \multirow[t]{2}{*}{$0.40^{*}$} \\
\hline Not present & $3.46 \pm 0.41$ & \\
\hline
\end{tabular}


a

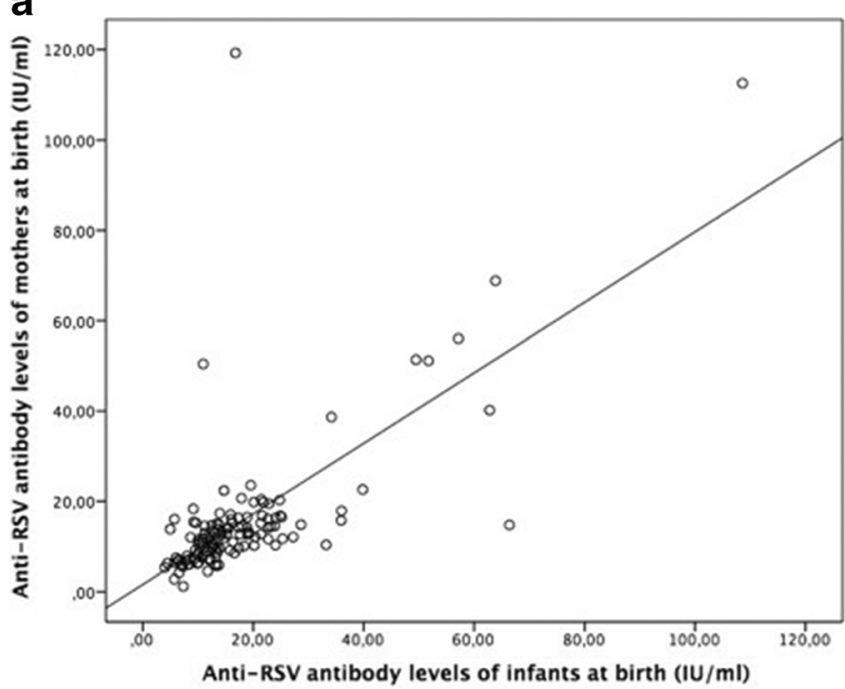

b

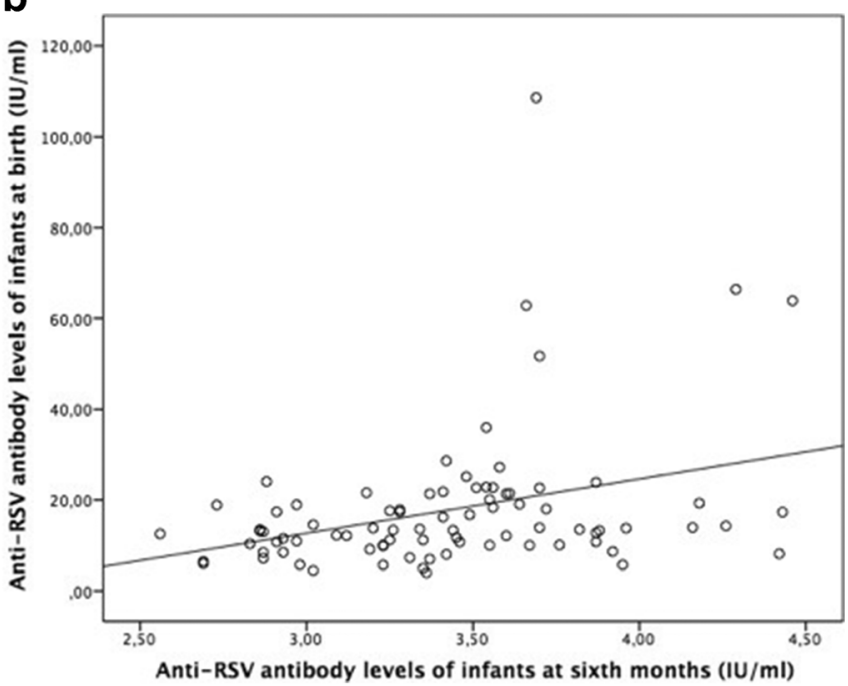

Fig. 3 a Correlation graph of maternal antibody levels and babies' antibody levels at birth. b Correlation graph of antibody levels of infants at birth and 6th month

\section{Conclusions}

The vaccine development efforts against RSV have accelerated in recent years because of its important effect on public health. A significant positive correlation between maternal antibody levels and infants' antibody levels at birth that we have reported in this study suggests that maternal vaccination strategies may be logical. We have pointed out that antibody transfer rate was highest in AGA infants. It should be kept in mind that maternal vaccination strategies may be less effective in LGA and SGA infants. Further prospective studies are needed to investigate the effect of birth weight on antibody transfer rate.

Authors' contribution Dr. Unuvar conceptualized and designed the study. Dr. Somer, Dr. Coban, and Dr. Torun drafted the initial manuscript and reviewed and revised the manuscript. Dr. Agacfidan, Dr. Mese, and Demircili carried out the analyses. Dr. Yildız, Dr. Kara, Dr. Sivrikoz, and Dr. Sutcu designed the data collection instruments, collected data, and reviewed and revised the manuscript.

Funding information This work was supported by Scientific Research Projects Coordination Unit of Istanbul University. Project number TTU2016-23288".

\section{Compliance with ethical standards}

Ethical approval This study was found to be ethically acceptable by Istanbul University Istanbul Medical Faculty Clinical Research Ethics Committee (2015/1816).

Statement of informed consent Written informed consent was obtained from all of the participants' parents.

Financial disclosure All of the authors have indicated they have no financial relationships relevant to this article to disclose.
Conflict of interest All of the authors have indicated they have no potential conflicts of interest to disclose.

\section{References}

1. Shi T, McAllister DA, O'Brien KL, Simoes EAF, Madhi SA, Gessner BD, Polack FP, Balsells E, Acacio S, Aguayo C, Alassani I, Ali A, Antonio M, Awasthi S, Awori JO, AzzizBaumgartner E, Baggett HC, Baillie VL, Balmaseda A, Barahona A, Basnet S, Bassat Q, Basualdo W, Bigogo G, Bont L, Breiman RF, Brooks WA, Broor S, Bruce N, Bruden D, Buchy P, Campbell S, Carosone-Link P, Chadha M, Chipeta J, Chou M, Clara W, Cohen C, de Cuellar E, Dang DA, Dash-Yandag B, Deloria-Knoll M, Dherani M, Eap T, Ebruke BE, Echavarria M, de Freitas Lazaro Emediato CC, Fasce RA, Feikin DR, Feng L, Gentile A, Gordon A, Goswami D, Goyet S, Groome M, Halasa N, Hirve S, Homaira N, Howie SRC, Jara J, Jroundi I, Kartasasmita CB, Khuri-Bulos N, Kotloff KL, Krishnan A, Libster R, Lopez O, Lucero MG, Lucion F, Lupisan SP, Marcone DN, McCracken JP, Mejia M, Moisi JC, Montgomery JM, Moore DP, Moraleda C, Moyes J, Munywoki P, Mutyara K, Nicol MP, Nokes DJ, Nymadawa P, da Costa Oliveira MT, Oshitani H, Pandey N, Paranhos-Baccala G, Phillips LN, Picot VS, Rahman M, Rakoto-Andrianarivelo M, Rasmussen ZA, Rath BA, Robinson A, Romero C, Russomando G, Salimi V, Sawatwong P, Scheltema N, Schweiger B, Scott JAG, Seidenberg P, Shen K, Singleton R, Sotomayor V, Strand TA, Sutanto A, Sylla M, Tapia MD, Thamthitiwat S, Thomas ED, Tokarz R, Turner C, Venter M, Waicharoen S, Wang J, Watthanaworawit W, Yoshida LM, Yu H, Zar HJ, Campbell H, Nair H (2017) Global, regional, and national disease burden estimates of acute lower respiratory infections due to respiratory syncytial virus in young children in 2015: a systematic review and modelling study. Lancet (London, England) 390(10098):946-958. https://doi.org/10.1016/s01406736(17)30938-8

2. Rudan I, O'Brien KL, Nair H, Liu L, Theodoratou E, Qazi S, Lukšić I, Fischer Walker CL, Black RE, Campbell H, Child Health Epidemiology Reference G (2013) Epidemiology and etiology of childhood pneumonia in 2010: estimates of incidence, severe morbidity, mortality, underlying risk factors and causative pathogens 
for 192 countries. J Glob Health 3(1):010401-010401. https://doi. org/10.7189/jogh.03.010401

3. Rudan I, Boschi-Pinto C, Biloglav Z, Mulholland K, Campbell H (2008) Epidemiology and etiology of childhood pneumonia. Bull World Health Organ 86(5):408-416. https://doi.org/10.2471/blt.07. 048769

4. Liu P, Xu M, He L, Su L, Wang A, Fu P, Lu L, Wang C, Xu J (2018) Epidemiology of respiratory pathogens in children with lower respiratory tract infections in Shanghai, China, from 2013 to 2015. Jpn J Infect Dis 71(1):39-44. https://doi.org/10.7883/yoken.JJID. 2017.323

5. Bharaj P, Sullender WM, Kabra SK, Mani K, Cherian J, Tyagi V, Chahar HS, Kaushik S, Dar L, Broor S (2009) Respiratory viral infections detected by multiplex PCR among pediatric patients with lower respiratory tract infections seen at an urban hospital in Delhi from 2005 to 2007 . Virol J 6:89. https://doi.org/10.1186/1743422x-6-89

6. Ralston SL, Lieberthal AS, Meissner HC, Alverson BK, Baley JE, Gadomski AM, Johnson DW, Light MJ, Maraqa NF, Mendonca EA, Phelan KJ, Zorc JJ, Stanko-Lopp D, Brown MA, Nathanson I, Rosenblum E, Sayles S 3rd, Hernandez-Cancio S (2014) Clinical practice guideline: the diagnosis, management, and prevention of bronchiolitis. Pediatrics 134(5):e1474-e1502. https://doi.org/10. 1542/peds.2014-2742

7. ACOG Committee Opinion No 579: Definition of term pregnancy (2013). Obstet Gynecol 122 (5):1139-1140. doi:https://doi.org/10. 1097/01.AOG.0000437385.88715.4a

8. Mikolajczyk RT, Zhang J, Betran AP, Souza JP, Mori R, Gulmezoglu AM, Merialdi M (2011) A global reference for fetalweight and birthweight percentiles. Lancet (London, England) 377(9780):1855-1861. https://doi.org/10.1016/s0140-6736(11) 60364-4

9. Chu HY, Steinhoff MC, Magaret A, Zaman K, Roy E, Langdon G, Formica MA, Walsh EE, Englund JA (2014) Respiratory syncytial virus transplacental antibody transfer and kinetics in mother-infant pairs in Bangladesh. J Infect Dis 210(10):1582-1589. https://doi. org/10.1093/infdis/jiu316

10. Chu HY, Tielsch J, Katz J, Magaret AS, Khatry S, LeClerq SC, Shrestha L, Kuypers J, Steinhoff MC, Englund JA (2017) Transplacental transfer of maternal respiratory syncytial virus (RSV) antibody and protection against RSV disease in infants in rural Nepal. J Clin Virol 95:90-95. https://doi.org/10.1016/j.jcv. 2017.08.017

11. Okoko JB, Wesumperuma HL, Hart CA (2001) The influence of prematurity and low birthweight on transplacental antibody transfer in a rural west African population. Tropical Med Int Health 6(7): 529-534. https://doi.org/10.1046/j.1365-3156.2001.00741.x

12. Yeung CY, Hobbs JR (1968) Serum- $\gamma$ G-globulin levels in normal, premature, post-mature, and "small-for-dates" newborn babies. Lancet 291(7553):1167-1170. https://doi.org/10.1016/S01406736(68)91865-5

13. Addy DP (1970) Cord serum IgG levels in "small-for-dates" babies. Arch Dis Child 45(244):809-810. https://doi.org/10.1136/adc.45. 244.809
14. Park WJ (2014) Seroprevalence of respiratory syncytial virus IgG among healthy young adults in basic training for the Republic of Korea air force. J Korean Med Sci 29(9):1325-1327. https://doi. org/10.3346/jkms.2014.29.9.1325

15. Eick AA, Faix DJ, Tobler SK, Nevin RL, Lindler LE, Hu Z, Sanchez JL, MacIntosh VH, Russell KL, Gaydos JC (2011) Serosurvey of bacterial and viral respiratory pathogens among deployed U.S. service members. Am J Prev Med 41(6):573-580. https://doi.org/10.1016/j.amepre.2011.08.006

16. Hacimustafaoglu M, Celebi S, Aynaci E, Sinirtas M, Koksal N, Kucukerdogan A, Ercan I, Goral G, Ildirim I (2004) The progression of maternal RSV antibodies in the offspring. Arch Dis Child 89(1):52-53. https://doi.org/10.1136/adc.2002.017780

17. Suara RO, Piedra PA, Glezen WP, Adegbola RA, Weber M, Mulholland EK, Greenwood BM, Whittle H (1996) Prevalence of neutralizing antibody to respiratory syncytial virus in sera from mothers and newborns residing in the Gambia and in the United States. Clin Diagn Lab Immunol 3(4):477-479

18. Forster J, Tacke U, Krebs H, Streckert HJ, Werchau H, Bergmann RL, Schulz J, Lau S, Wahn U (1996) Respiratory syncytial virus infection: its role in aeroallergen sensitization during the first two years of life. Pediatr Allergy Immunol 7(2):55-60

19. Arankalle VA, Kulkarni R, Malshe N, Palkar S, Lalwani S, Mishra AC (2019) Seroepidemiology of respiratory syncytial virus in western India with special reference to appropriate age for infant vaccination. J Med Virol 91(8):1566-1570. https://doi.org/10.1002/jmv. 25489

20. Heijtink RA, Backx G, Van Der Horst JM, Masurel N (1977) Complement fixation and neutralization RS antibodies in maternal and neonatal sera. J Hyg 78(3):411-417. https://doi.org/10.1017/ s0022172400056308

21. Cox MJ, Azevedo RS, Cane PA, Massad E, Medley GF (1998) Seroepidemiological study of respiratory syncytial virus in Sao Paulo state, Brazil. J Med Virol 55(3):234-239

22. Bhattarakosol P, Pancharoen C, Mungmee V, Thammaborvorn R, Semboonlor L (2003) Seroprevalence of anti-RSV IgG in Thai children aged 6 months to 5 years. Asian Pac J Allergy Immunol 21(4):269-271

23. Nyiro JU, Sande C, Mutunga M, Kiyuka PK, Munywoki PK, Scott JA, Nokes DJ (2015) Quantifying maternally derived respiratory syncytial virus specific neutralising antibodies in a birth cohort from coastal Kenya. Vaccine 33(15):1797-1801. https://doi.org/10.1016/ j.vaccine.2015.02.039

24. Le Saux N, Gaboury I, MacDonald N (2003) Maternal respiratory syncytial virus antibody titers: season and children matter. Pediatr Infect Dis J 22(6):563-564. https://doi.org/10.1097/00006454200306000-00015

Publisher's note Springer Nature remains neutral with regard to jurisdictional claims in published maps and institutional affiliations. 